\title{
Effects of Natural Products on Acute Orofacial Pain Control Enhanced by Oral Disease
}

\author{
Ja-Hyeong Choi ${ }^{1, ; * *}$ and Min-Kyung Lee ${ }^{2,3, *}$ \\ ${ }^{I}$ Department of Dental Hygiene, Kyung-Woon University, Gumi 39160, Korea \\ ${ }^{2}$ Department of Dental Hygiene, Dong-Eui University, Busan 47340, Korea \\ ${ }^{3}$ The Research Institute Health for Functional Material, Busan 47340, Korea
}

\begin{abstract}
As the interest in oral health is increasing with quality of life. The most representative oral diseases include dental caries, periodontal disease, and malocclusion, as well as dry mouth and oral mucosa. Cinnamaldehyde have an antioxidant effect that has been studied not only to treat rheumatism and hypertension, but also to protect liver, and gastrointestinal tract, but there are few studies related to the control of oral diseases. The purpose of this study was the effect of enhanced orofacial pain when oral administration of cinnamaldehyde in the oral diseases. Cinnamaldehyde $(5,12.5,25$, and $50 \mathrm{mg} /$ $\mathrm{kg}$ ) orally administered at a dose of $1 \mathrm{~mL}$, and the change in biological response was confirmed after a week. In addition, $5 \%$ formalin $(30,50 \mu \mathrm{L})$ was injected into TMJ and subcutaneous areas of the whiskers of rats to observe the change in the threshold of the improved orofacial pain model. As a result of the experiment, in the xerostomia model, drinking water was decreased in the cinnamaldehyde-administered group, feed intake and weight increased, and saliva was also increased compared to the naïve group. In particular, the most significant increase trend was observed at the concentrations of 25 and $50 \mathrm{mg} / \mathrm{kg}$. In addition, it was confirmed that the pain behavioral response of the orofacial area improved by oral diseases decreased depending on the concentration of cinnamaldehyde. Based on these results, cinnamaldehyde effectively reduced symptoms related to xerostomia and showed improved pain relief in the orofacial areas.
\end{abstract}

Key Words: Oral disease, Cinnamaldehyde, Submandibular gland, Orofacial pain

서 론

과거에 비하여 경제 성장의 발달로 인한 영양상태의 개 선으로 신체의 성장 발달이 개선되었으나 당질의 함량이 높은 가공식품의 무분별한 잦은 섭취 등의 식생활의 변 화로 구강건강상태가 점점 악화되고 있는 실정이다(Song and Moon, 2002). 구강질환은 현재 세계에서 흔히 발생되 는 건강 문제 중 하나로(Myburgh et al., 2004) 구강건강상 태와 삶의 질과의 관련성이 입증되면서 삶의 질의 만족
도 상승 요인에 있어 구강 건강에 관한 관심이 증대되고 있다(Mariño et al., 2008). 가장 대표적인 구강질환으로는 치아우식증, 치주병, 부정교합을 호소하는 경우가 많으 며 그 외에 구강건조증, 구강점막질환 등이 있다. 그 중 구강건조증은 여러 구강 기능에 영향을 미치며 불편감, 통증 등으로 개인의 삶의 질을 저하시키는 질환으로 타 액 흐름의 감소 또는 타액 분비 저하를 통하여 충치, 구 강 병변, 치주염, 미각의 변화, 점액성 타액 분비, 저작감, 침샘 감염, 진균 감염 등과 같은 결과로 나타날 수 있다 (Atkinson et al., 2005). 구강건조증은 다양한 약물 및 생물

Received: November 16, 2020 / Revised: December 8, 2020 / Accepted: December 10, 2020

*Professor.

†Corresponding author: Ja-Hyeong Choi. Department of Dental Hygiene, Kyung-Woon University, 730, Gangdong-ro, Sandong-myeon, Gumi-si, Gyeongsangbuk-do 39160, Korea.

Tel: +82-54-479-4066, Fax:+82-54-479-4119, e-mail:ng486c@hanmail.net

(C) The Korean Society for Biomedical Laboratory Sciences. All rights reserved.

(c) This is an Open Access article distributed under the terms of the Creative Commons Attribution Non-Commercial License (http://creativecommons.org/licenses/by-nc/3.0/) which permits unrestricted non-commercial use, distribution, and reproduction in any medium, provided the original work is properly cited. 
학적인 요인 및 스트레스, 불안감, 우울증과 같은 심리적 인 요인이 원인으로 볼 수 있는데, 생리적 요인으로 세포 수 감소 및 세포 기능 저하, 근육 기능 감소와 같은 노화 로 인한 퇴행성 변화 등으로 자율신경계 기능이 저하된 다(Yasuko et al., 1998). 또한 노령화 사회로 평균 수명이 연장되어 전신질환 인구 증가와 더불어 장기간 약물 복 용 기간과 관련되어 있다. 알츠하이머병 및 파킨슨 질환, 삼환계 항우울제, 고혈압제재의 복용 등의 전신질환에 의 한 약물 복용을 비롯하여, 두경부 암 치료 방법인 방사선 요법으로도 타액선 손상에 영향을 미친다(Yair et al., 2015). 아트로핀, 글리코피롤레이트 등과 같은 항콜린제는 암 수술의 전 처지 약물로써 타액의 분비를 감소시키는데, 이는 타액선에 분포하는 무스카린 수용체의 길항 작용으 로 부교감 신경을 억제함으로써 결과적으로 구강 점막 을 건조하게 한다는 연구 결과가 있다(Miranda et al., 2015). Silverman의 연구에서는 인체 내로 조사되는 방사선이 타 액선 조직 내에 지방 변성, 섬유화, 세포 성분의 괴사 및 선포의 위축 등의 비가역적인 손상을 일으켜 구강건조증 을 유발할 뿐만 아니라 타액의 $\mathrm{pH}$ 감소가 이루어진다고 보고하였다(Silverman, 1999). 현재 대표적인 구강건조증의 치료제는 미국 식품의약국(FDA)의 승인을 받은 세비멜린 (Cevimeline) 및 필로카르핀(Pilocarpine)이 주로 처방되는 데, 세비멜린은 $\mathrm{M} 3$ 무스카린 수용체와 강한 결합력을 가 진 타액선 자극제이며 필로카르핀은 무스카린 수용체 중 부교감 신경을 자극하는 약물이다(Choi and Lim, 2016). 효 능이 좋은 반면에 부작용도 적지 않은데, 설사, 기관지 축소, 빈맥, 오심 및 구토, 저혈압, 시야의 이상, 땀 분비 의 증가, 저혈압, 피부 혈관의 확장 등의 부작용이 보도되 고 있다(Aframian et al., 2007). 뿐만 아니라 비 조절성 고혈 압 환자 및 급성 위궤양 환자에겐 제한적 처방을 하고 베타 차단제 사용 중인 환자, 비 조절성 천식 환자, 만성 폐질환 환자에겐 처방을 금한다(Aframian et al., 2007).

노인 집단에서 주로 호소하는 구강건조증으로 인하여 다양한 연관통을 호소하는 것으로 알려져 있는데, 구강 안면부는 다양한 구조 및 기능으로 구성되어 있으며 신 경의 분포가 복잡하고 조밀하여 통증이나 질병이 발생했 을 경우 복잡하고 다양한 임상 증상으로 나타나는 경우 가 많다. 실제 구강안면부의 통증으로 인하여 치과를 내 원하는 비중이 높은 편인데 급성과 만성, 복합성으로 발 생하는 구강안면부 통증(orofacial pain)은 안면부, 두부 및 구강 내 구조물의 경조직 및 연조직에 나타나는 통증이 포함되는 용어로, 치아질환을 비롯한 구강 운동 장애를
유발하며 측두하악관절 장애(temporomandibular disorder, $\mathrm{TMD})$ 를 비롯한 삼차신경통과 같은 신경병증성 통증 발 현까지 다양한 질환들이 유사한 형태의 동통으로 나타나 진단이 어려운 경우가 많다(Choi et al., 2006). 두통이나 신 경성 통증, 근골격성 통증, 심인성 통증, 암 등으로 인해 발생되는 통증을 포함하며, 유발되는 전달 과정에 산화적 스트레스가 높게 작용하는 것으로 알려져 있다(Choi et al., 2006).

안면부 통증은 손상된 조직의 세포 및 말초신경의 말단 부위 등에서 prostaglandin, histamine, adenosine 5 'triphosphate (ATP), substance P, bradykinin, 등의 염증성 물질들이 유리 되어 발생한다(Kim, 2006). 통증을 유발하는 흥분성 신경 전달물질인 ATP는 퓨린(purine)계 물질들과 반응되는 수 용체에 결합되면 이온 채널이 열리며 세포막을 통과하여 막전위가 변화된다(Dunn et al., 2001). 흥분성 통각정보가 $\mathrm{C}$ 섬유 및 $\mathrm{A}-\delta$ 섬유 등의 유해수용기(nociceptors)에 의해 감작되어 척수에 전달되면 일련의 처리 과정을 척수 후 각에서 대뇌 피질로 전달되어 통증을 자각하게 되는 것 이다(Kim, 2006).

안면부 통증으로 인한 치료 방법으로 대개 비스테로이 드성 약물이 많이 처방되는데, 이 약물은 진통 효과가 뛰 어나지만 장기간 복용 시 혈전증 및 위장관 독성 반응 등 의 부작용도 발생될 수 있어 주의가 필요하다(Kim and Lee, 2015). 합성의약품에 비해 최근에는 비교적 독성이 적고 장기 복용이 가능하며 복합적인 효능을 가진 천연 물질에 대한 연구가 활발히 진행되고 있으며 관심이 높 아지고 있다. 최근 연구에 따르면, 구강안면 부위에 흰 쥐의 실험동물에서 급성 통증을 유발한 뒤 용규, 포공영, 마치현, 토복령 추출물을 투여 시 통증이 경감되는 효과 가 보고되었으며(Kim et al., 2018), Choi 등의 연구에서 보 스웰리아 추출물의 경구 투여 시 formalin으로 유도된 안 면부 및 악관절 통증 모델에서 통증 행위 반응이 유의하 게 감소하였다는 결과가 보고되었다(Choi et al., 2018).

최근에는 앞서 열거한 합성의약품의 부작용을 최소화 하기 위해 구강건조증을 비롯한 다양한 질환을 대상으로 천연 약물 치료법이 증대되고 있다. 천연 물질은 비교적 낮은 독성 성분과 장기 복용에 초래되는 부작용이 낮은 반면 약리적 효능을 기대할 수 있어 천연 물질에 대한 관심이 높아지고 있다(Braga et al., 2009). 고대부터 동양 및 서양에서는 항산화제와 향신료와 식품 부패 박테리아 및 다양한 병원균의 증식을 억제하기 위하여 여러 천연 물질에서 약리 효능을 확보해왔다. 본 연구에서 사용된 
cinnamaldehyde는 cinnamon oil의 주성분으로 녹나무 속에 속하는 것으로 폴리페놀 성분이 풍부하여 높은 항산화 작용을 향상 시키는 것으로 알려져 있다. 염증이나 요로 감염이나 위장 장애 및 염증을 비롯한 질병의 치료 목 적의 건강증진 물질인자로 사용되고 있으며(Brierley and Kelber, 2011), cinnamon 나무껍질 3 6 g을 복용하면 제2 형 당뇨 환자에게 감소된 혈당 수치 변화를 보고하였다 (Alam et al., 2003). 구강 건강 관련해서는 구취 제거, 치통, 구강 감염에도 탁월한 효과가 있는 것으로 알려져 있다 (Chaudhary et al., 2013). 뿐만 아니라 설사 방지제, 강력한 항염제, 각성제, 항응고제 효과를 비롯하여(Hossein et al., 2013), 혈액 응고 작용이 있어 출혈이 발생했을 경우 지 혈제로도 사용 가능하다(Rao and Gan, 2014). 본 연구에서 도 구강질환으로 향상된 구강안면부 통증의 조절에 천 연 약물로서의 다양한 생리학적 효능이 밝혀진 cinnamaldehyde가 효과적일 것으로 기대하여 본 연구를 진행하 였다.

따라서 본 연구에서는 최의 선행 논문을 참고하여(Choi et al., 2020) 4-DAMP를 복강 내로 투여하여 구축된 구강 건조증 모델에서 생체 반응 변화를 관찰하고, 대표적으로 구강질환이 유발되는 부위인 실험동물의 안면부 및 턱관 절 부위에서 formalin으로 유도된 염증성 통증 모델에서 의 cinnamaldehyde 통증 행위 반응 조절 효과에 대해 확 인하고자 하였다. 우선 cinnamaldehyde를 경구 투여(Oral administration)하여 음수 량, 체중, 식이 섭취량, 타액 량을 비교하여 구강건조증에 기인하는 생체 변화를 확인하고 자 하였다. 또한 향상된 안면부 통증의 역치 변화를 관찰 해 보고자 4-DAMP를 투여하여 구강건조증을 유발시킨 실험동물에 우측 수염부 피하 및 $\mathrm{TMJ}$ 에 $5 \%$ formalin을 주입하여 통증의 변화를 확인하였고, cinnamaldehyde의 경 구 투여한 뒤 구강건조증을 유발시키고 formalin을 동일 한 부위에 투여한 경우 통증 조절 효과가 나타나는지 확 인하고자 하였다.

\section{재료 및 방법}

\section{실험동물}

본 실험 연구에서 사용된 실험동물은 효창사이언스(대 구)에서 공급 받았으며 생후 6 7주령의 Sprague-Dawley 계 수컷 흰 쥐였다. 동의대학교 동물 준비실에서 $23 \sim 26^{\circ} \mathrm{C}$ 온도와 12 시간 주.야간 빛의 순환 주기가 일정한 환경에 서 사육 및 유지하였다. 본 연구는 동의대학교 동물실험
윤리위원회에서 승인을 받았으며(R2018-011), 의식 있는 동물에 대한 통증연구학회에서 규정한 윤리 규범을 준수 하여 실험을 진행하였다.

\section{약물 제조 및 투여 방법}

4-DAMP 투여 및 타액 분비량 측정: 실험이 시작되기 30 분 전에 투명한 플라스틱 통에 실험동물을 적응시켜 스트레스를 최소화하였으며, 실험을 진행되기 전까지 사 료 및 물의 섭취를 일체 금하였으며 최의 선행 논문을 참고하여(Choi et al., 2020) 동일하게 진행하였다. 구강건조 증을 유발시키기 위하여 시그마 알드리치사(Sigma-Aldrich Co., St. Luis, U.S.A)에서 구입한 4-DAMP (1 mg/kg) 약물을 복강 내에 $1 \mathrm{~mL}$ 의 용량으로 투여(intraperitoneal)하였다. 시 간이 경과 한 뒤 안정 위 상태를 유지하기 위하여 $20 \%$ urethane을 $0.5 \mathrm{~mL} / \mathrm{kg}$ 의 용량으로 복강 투여하였다. 타액 분비량은 멸균된 면 구(cotton ball)를 실험동물의 구강 내 악하선의 분비관 개구 부위에 위치시킨 뒤 30 분간 무게 를 측정하였으며, 타액을 흡수한 무게를 타액 분비량으로 간주하였다.

Cinnamaldehyde의 약물 투여: Cinnamaldehyd는 시그마 알드리치사(Sigma-Aldrich Co., St. Luis, U.S.A)에서 구입하 였으며 20\% DMSO에 용해시킨 뒤 distilled water (D.W)에 $5,12.5,25,50 \mathrm{mg} / \mathrm{kg}(1 \mathrm{~mL})$ 의 농도 별로 희석하여 각각 1 회 경구 투여하여 일주일 간 반응을 관찰하고자 하였으 며 4-DAMP를 복강에 투여하기 30분 전에 먼저 실시하 였다.

구강건조증으로 변화된 생체 반응 측정: 구강건조증과 관 련된 생체 반응은 음수 량 식이 섭취량 및 체중으로 구 분하여 4-DAMP 투여 후 일주일 간 나타나는 변화를 측 정하였고, 유의한 변화를 나타낸 실험동물을 기준으로 구 강건조증 모델을 확립하였다. 최의 선행 논문을 참조하여 (Choi et al., 2020) 체중은 실험 전 후 측정하여 변화된 수 치를 확인하였으며 음수 량은 물병에 $250 \mathrm{~mL}$ 용량을 기 준으로 잔여량을 측정하였고 식이 섭취량도 $200 \mathrm{~g}$ 의 사료 를 공급한 뒤 잔여량을 측정하여 실제 복용량으로 간주 하여 측정하였다. 또한 cinnamaldehyde를 농도 별로 각각 경구 투여하고 30분 경과 후 4-DAMP를 복강 투여하여 구강건조증을 유발시킨 다음 생체 반응에 변화가 있는지 확인해 보고자 하였다. 
유발된 구강건조증 모델에서 안면부 염증성 통증 역치 변화: 실험동물의 복강 내 4-DAMP 투여로 구강건조증 을 유발시킨 다음 안면부에 $5 \%$ formalin을 주입하여 발 생되는 염증성 통증 역치의 변화를 관찰하였다. 복강 내 4-DAMP를 투여하고 30 분 경과 후 $5 \%$ formalin을 흰 쥐의 오른쪽 수염 부위에 $50 \mu \mathrm{L}$ 투여하여 안면부 염증성 통증 을 유발시켰으며, 약물이 주입된 부위를 벽에 문지르거나 긁는 행위를 통증 지표로 간주하였다. 생리식염수 $1 \mathrm{~mL}$ 를 복강 투여한 naïve군도 30 분이 경과한 뒤 동일한 부 위에 $5 \%$ formalin $50 \mu \mathrm{L}$ 의 동일 용량으로 투여하여 통증 행위 반응을 관찰하였으며 실험은 선행 논문을 참고하여 45 분 동안 5 분 단위로 행위 반응을 기록하였다(Yang et al., 2007).

유발된 구강건조증 모델에서 TMJ 통증 역치 변화: 폴리 에틸렌 튜브 끝에 cannula를 30 gauge 두께의 주사바늘을 연결시켰으며, 반대쪽에는 $0.25 \times 8 \mathrm{~mm}$ 의 주사기를 연결 하여 TMJ 내로 formalin을 투여하고자 하였다. 실험동물 에 에테르를 이용한 흡입 마취 후 하악 과두 부위와 관 골궁의 경계 부위를 촉지하여 관절강의 위치를 확인한 뒤 하악와의 닿는 부위까지 관절강 내로 주사바늘을 넣었다. Formalin $(30 \mu \mathrm{L})$ 를 $10 \mu \mathrm{L}$ 를 5 초 동안 관절강 내 투여하였 으며, 약물을 주입한 뒤 의식이 수 초 안으로 돌아오는 것을 확인하였다. TMJ 부위를 긁거나 벽에 문지르는 행 위 반응을 5 분 간격으로 9 회를 측정하여 총 45 분간 기록 하였으며 1차 통증 행위 반응(first phase)인 0 10분과 2차 통증 행위 반응(second phase)인 11 45분 구분하여 관찰하 였다.

통계 분석: IBM SPSS statistic ver. 20 (IBM Co., Armonk, NY, USA)을 사용하였으며 구강건조증으로 인하여 유발된 염 증성 안면부 통증 행위 반응에 대한 결과는 모두 평균 \pm 표준 오차(SEM)로 표시하였으며 $P<0.05$ 의 기준으로 통계 적으로 유의 하다고 평가하였다. 또한 일원분산분석을 시 행하여 반복 측정자료를 분석했으며 LSD post-hoc test를 이용하여 사후 분석을 실시하였다.

\section{결 과}

\section{Cinnamaldehyde 투여 후 생체 반응 변화}

Fig. 1은 cinnamaldehyde를 투여 후 구강건조증을 유발한 모델에서 나타나는 생체 반응의 변화이다. Naïve군, vehicle
군, 4-DAMP, cinnamaldehyde $5 \mathrm{mg} / \mathrm{kg}$ (C5), cinnamaldehyde $12.5 \mathrm{mg} / \mathrm{kg}$ (C12.5), cinnamaldehyde $25 \mathrm{mg} / \mathrm{kg}$ (C25), cinnamaldehyde $50 \mathrm{mg} / \mathrm{kg}$ (C50)으로 구분하여 실험을 진행하였 고 우선 안정 위 상태에서 음수 량, 식이 섭취량, 체중 및 타액 량을 측정한 뒤 일주일 간의 변화를 관찰하였다. 음수 량은 naïve군 $190 \mathrm{~mL}$, vehicle군 $167.5 \mathrm{~mL}, 4$-DAMP 군 $208.8 \mathrm{~mL}$ 를 음용한 반면 $\mathrm{C} 5$ 군은 $175 \mathrm{~mL}, \mathrm{C} 12.5$ 군은 $185 \mathrm{~mL}, \mathrm{C} 25$ 군은 $182.5 \mathrm{~mL}, \mathrm{C} 50$ 군은 $177.5 \mathrm{~mL}$ 로 나타나 구 강건조증이 유도된 4-DAMP군에서 음수 량이 증가하였 으며 cinnamaldehyde의 경구 투여군에서는 감소한 것을 확인하였다.

사료 섭취량은 naïve군 $162.5 \mathrm{~g}$, vehicle군 $155 \mathrm{~g}, 4$-DAMP 군 $97.5 \mathrm{~g}$ 이였으며, $\mathrm{C} 5$ 군은 $92.5 \mathrm{~g}, \mathrm{C} 12.5$ 군은 $105 \mathrm{~g}, \mathrm{C} 25$ 군 은 $142.5 \mathrm{~g}, \mathrm{C} 50$ 군은 $142.5 \mathrm{~g}$ 으로써 cinnamaldehyde를 투여 한 그룹에서 증가된 양상을 보였다.

체중의 변화는 naïve군 $225 \mathrm{~g}$, vehicle군 $235 \mathrm{~g}$, 4-DAMP 군에서는 $215 \mathrm{~g}$ 으로 나타난 반면 cinnamaldehyde를 투여 한 군에서 C5군은 $220 \mathrm{~g}, \mathrm{C} 12.5$ 군은 $235 \mathrm{~g}, \mathrm{C} 25$ 군은 $235 \mathrm{~g}$, C50군은 $227.5 \mathrm{~g}$ 으로 나타나 cinnamaldehyde를 투여한 군 에서 체중이 증가한 것으로 나타났다.

타액 분비량을 측정한 결과 naïve군은 $0.2520 \mathrm{~g}$ 과 vehicle 군 $0.2267 \mathrm{~g}$, 4-DAMP군에 $0.0030 \mathrm{~g}$ 이였으며 cinnamaldehyde 투여군에서는 $\mathrm{C} 5$ 군 $0.0016 \mathrm{~g}, \mathrm{C} 12.5$ 군 $0.0039 \mathrm{~g}, \mathrm{C} 25$ 군 $0.1441 \mathrm{~g}, \mathrm{C} 50$ 군은 $0.150 \mathrm{~g}$ 으로 cinnamaldehyde 투여군이 농도 의존적으로 타액 분비량이 증가한 것을 확인할 수 있었다.

\section{구강건조증 유발 후 안면부 염증성 통증 역치 변화}

Fig. 2는 4-DAMP를 투여하여 구강건조증을 유발시킨 실험군에서 안면부에 $5 \%$ formalin을 주입하여 나타나는 염증성 통증의 역치 변화를 나타내었다. Naïve군은 37.24 \pm 1.21 회, control군은 $302.5 \pm 18.8$ 회였으며 D.W와 formalin 을 투여한 vehicle군에서는 $315.7 \pm 11.7$ 인 반면 $478.7 \pm 17.5$ 회인 4-DAMP군에서는 증가하였으며 $(P<0.05)$, 시간에 따 른 변화를 살펴보면 20 분에서 40 분 실험 시점에서 통증 행위 반응이 증가한 것을 확인할 수 있었으며 통계적으 로도 유의하였다.

\section{구강건조증 유발 후 TMJ 염증성 통증 역치 변화}

TMJ에서의 통증 역치 변화는 Fig. 3에 나타내었다. 앞 서 안면부 통증 변화 수치와 동일하게 4-DAMP 투여군에 서도 통증의 감수성이 더 높은 것으로 확인되었다. Naïve 

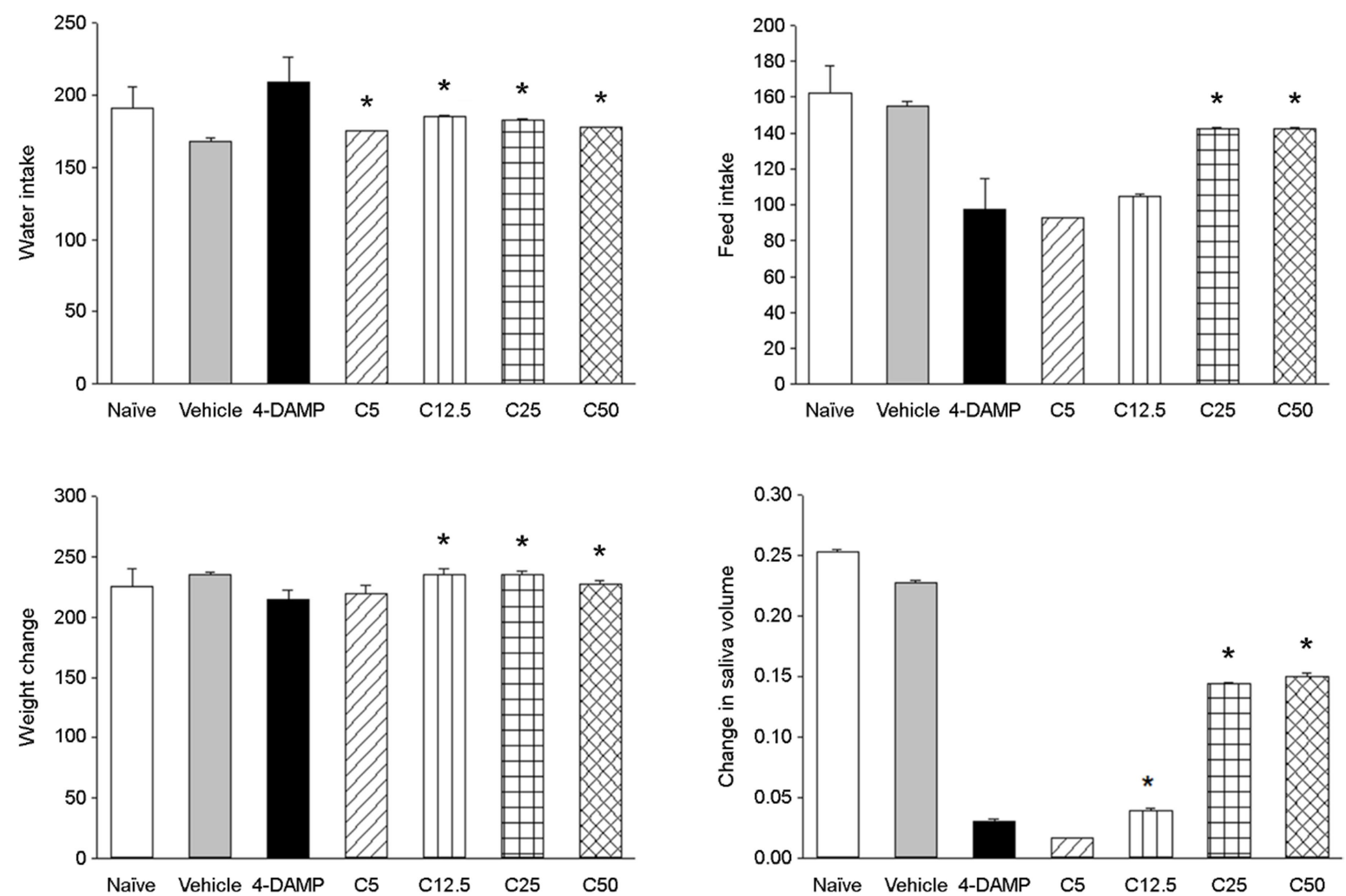

Fig. 1. Bioresponse following by 4-DAMP injection and cinnamaldehyde $(5,12.5,25,50 \mathrm{mg} / \mathrm{kg})$ for 1 week compared control group and vehicle group $\left({ }^{*} P<0.05\right.$, vs 4-DAMP, $\left.\mathrm{n}=6\right)$.
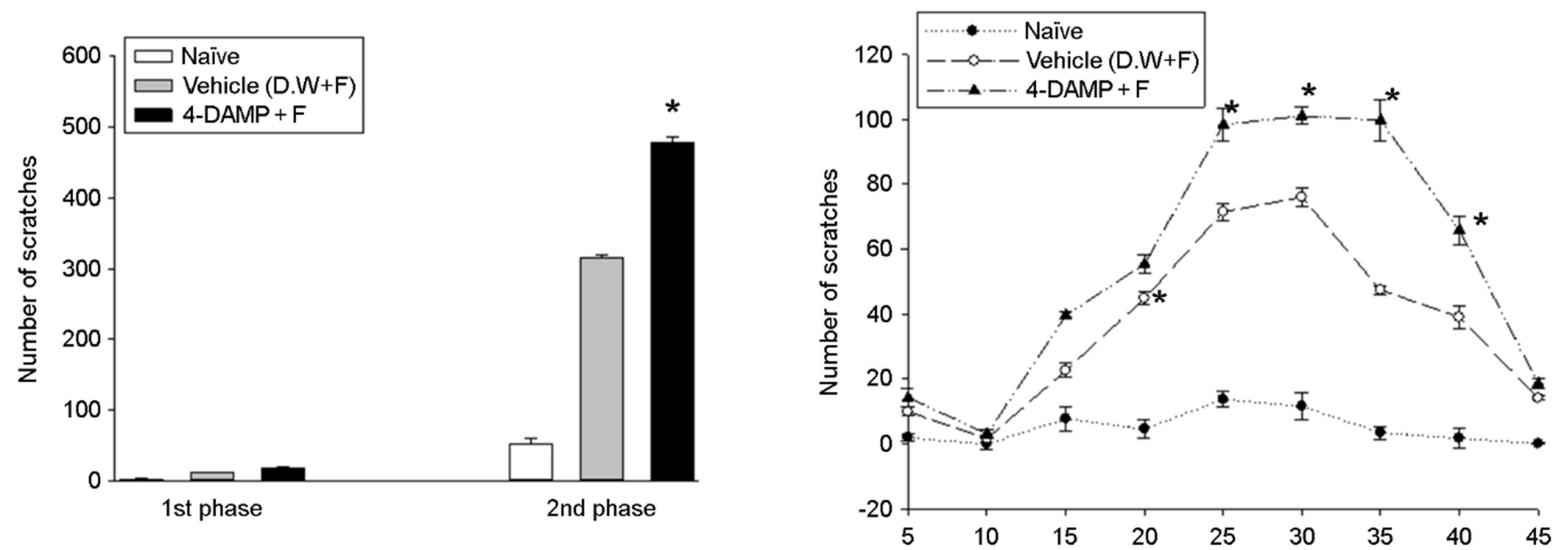

Fig. 2. Nociceptive behavior responses increased following orofacial intraperitoneal injection of 4-DAMP $(1 \mathrm{mg} / \mathrm{kg})(\mathrm{n}=6$, respectively). ${ }^{*} P<0.05$, vs Vehicle + F (Formalin, F).

군 $91 \pm 14.5$ 회, vehicle군 $132 \pm 8.2$ 회인 것인 반면 4-DAMP 군에서는 $251 \pm 11$ 회로 증가한 것을 확인할 수 있었으며 시간에 따른 변화는 15 30분 경과 시점에서 통증 행위가 증가하였고 통계적으로 유의하였다.
안면부 염증성 통증 변화에 cinnamaldehyde 투여가 미 치는 영향

Fig 4는 cinnamaldehyde 투여로 안면부 염증성 통증 변

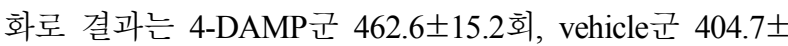



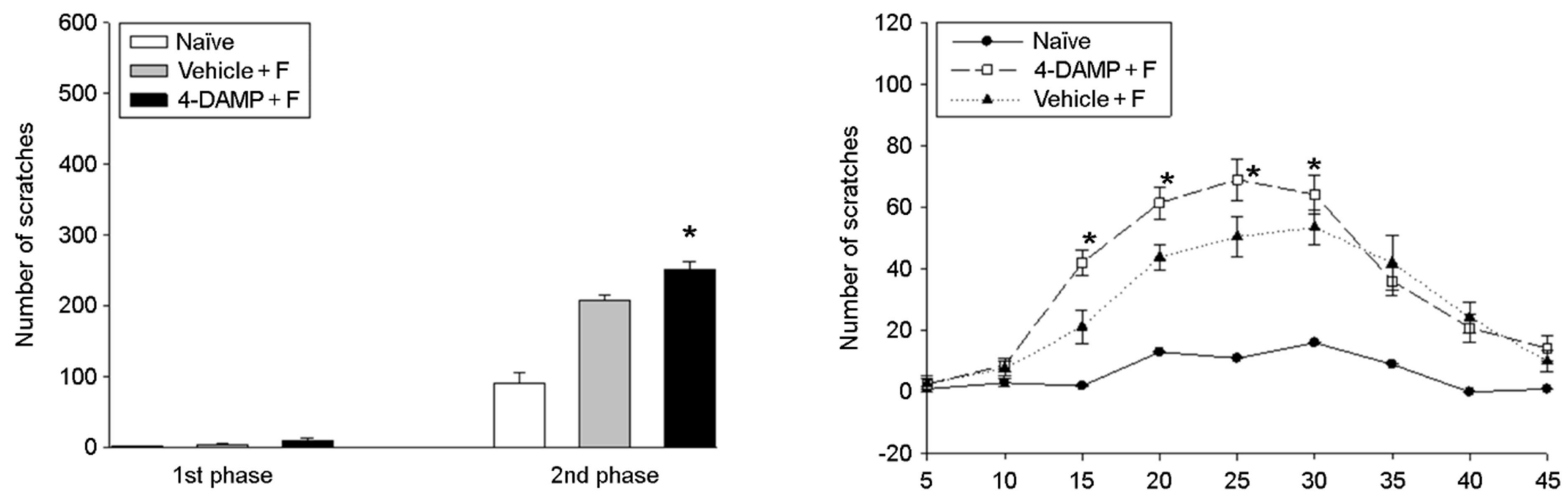

Fig. 3. Nociceptive behavior responses increased following TMJ intraperitoneal injection of 4-DAMP (1 $\mathrm{mg} / \mathrm{kg})(\mathrm{n}=6$, respectively). ${ }^{*} P<0.05$, vs Vehicle + F (Formalin, F).
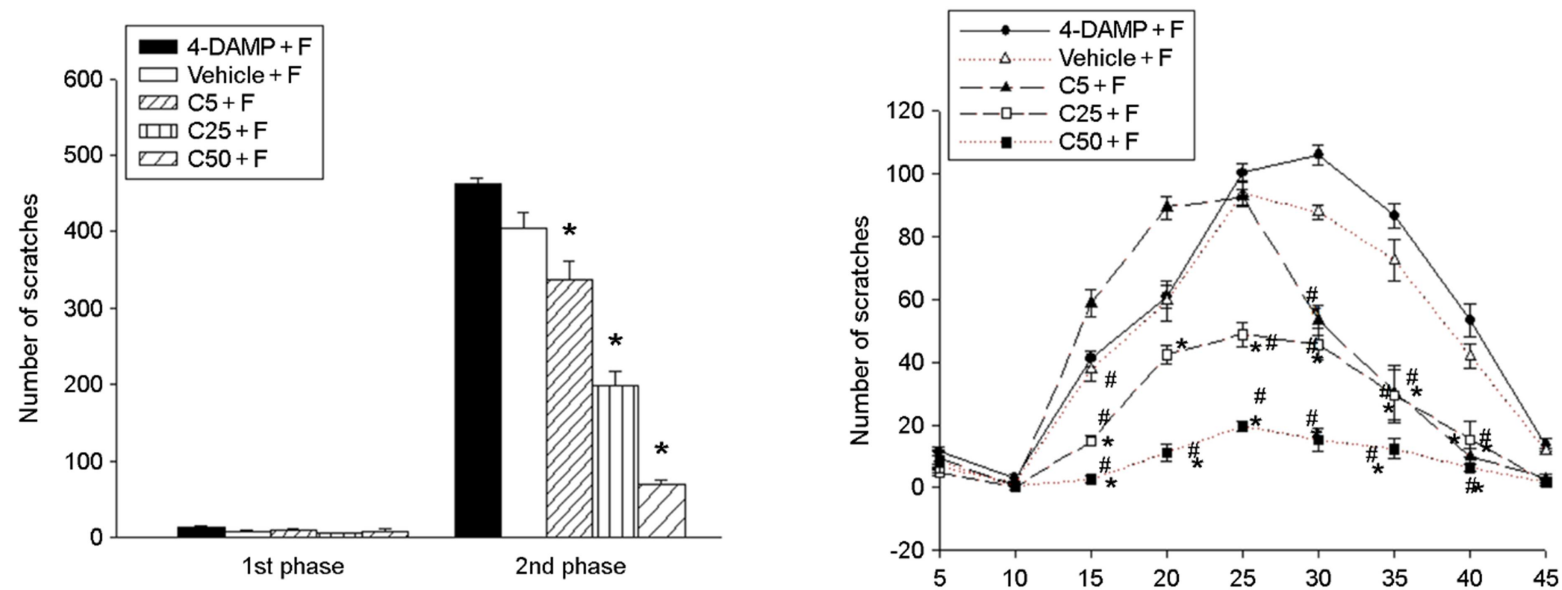

Fig. 4. Effects of cinnamaldehyde in orofacial on nociceptive behavior. Changes in nociceptive responses following administration of cinnamaldehyde. ${ }^{*} P<0.05$, vs $4-\mathrm{DAMP}+\mathrm{F},{ }^{\#} P<0.05$, VS vehicle $+\mathrm{F}$ (Formalin, $\mathrm{F}$ ), $\mathrm{n}=6$ ).
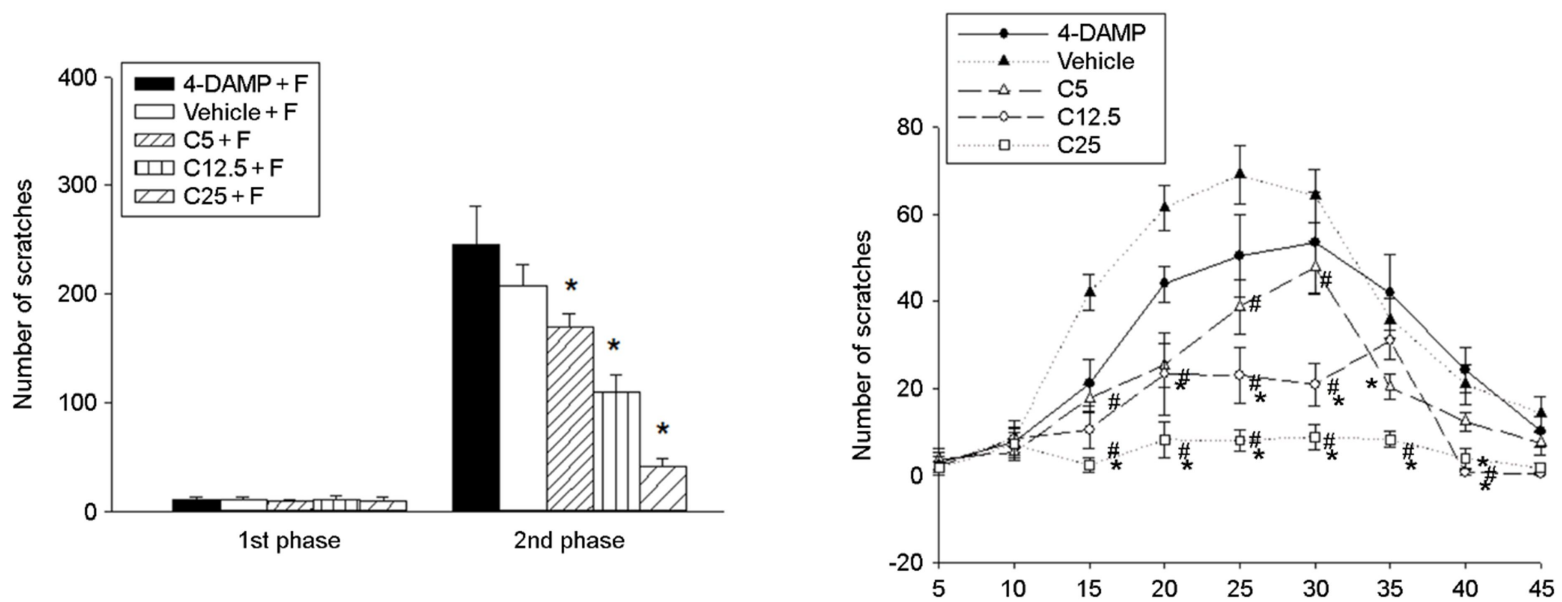

Fig. 5. Effects of cinnamaldehyde in orofacial on nociceptive behavior. Changes in nociceptive responses following administration of cinnamaldehyde. ${ }^{*} P<0.05$, vs $4-\mathrm{DAMP}+\mathrm{F},{ }^{\sharp} P<0.05$, VS vehicle $+\mathrm{F}$ (Formalin, $\mathrm{F}$ ), $\mathrm{n}=6$ ). 
8.71회로 나타났으며 cinnamaldehyde 투여군에서는 C5군 $337.5 \pm 9.83$ 회, $\mathrm{C} 25$ 군 $198.3 \pm 5.17$ 회, $\mathrm{C} 50$ 군 $69 \pm 8.83$ 회로 통증 행위 반응 횟수가 통계적으로 유의하게 감소하였으 며 시간 경과 별 결과에서는 $15 \sim 40$ 분 지점에서 통계적으 로 유의한 감소된 수치로 관찰되었다.

\section{TMJ 통증 변화에 cinnamaldehyde 투여가 미치는 영향}

Fig 5는 cinnamaldehyde를 경구 투여한 후 4-DAMP를 복강 투여하여 구강건조증을 유발시킨 모델에서 $\mathrm{TMJ}$ 에 염증성 통증 행위 변화이다. 4-DAMP군 251.8 \pm 8.8 회, vehicle군 $112 \pm 11.2$ 회였고, cinnamaldehyde를 투여한 뒤 결 과는 $\mathrm{C} 5$ 군은 $169.3 \pm 9$ 회, $\mathrm{C} 12.5$ 군은 $198.3 \pm 8.5$ 회, $\mathrm{C} 25$ 군은 $41 \pm 8.83$ 회로써 농도 의존적으로 통증이 감소한 것을 확 인할 수 있었으며 통계적으로 유의하였다. 시간의 경과 에 따른 결과는 $15 \sim 40$ 분 지점인 2차 통증 행위 반응에서 naïve군에 비하여 통계적으로 유의하게 감소되었다.

\section{고 찰}

안면부 통증은 일생 동안 최소 $70 \%$ 이상의 사람들이 치과에서 환자들이 호소하는 질환이다(Lee et al., 2017). 통증 발생 원인은 구강 내 요인으로 발생되는 통증과 근 육질환 및 턱관절을 포함하는 TMD (Temporomandibular joint dysfunction)가 가장 빈번하게 나타난다(Dworkin and LeResche, 1992). 염증 발생이나 조직 손상 등으로 발생되 는 통증은 불쾌한 감각증세와 심리적 경험을 통해 통증 성 신경전달물질이 유리되며 세포막의 수용기에 흥분성 활동전위가 작용하게 된다(Richard and Clifford, 2000). 현재 통증의 정도를 조절을 위하여 물리요법, 약물요법, 레이 저 치료, 전기 치료 등이 개발되어 이용되고 있으나 상대 적으로 부작용이 적은 천연 물질에 대한 관심이 높아지 고 있으며, 실제로 임상적으로 다양하게 활용 중이다.

최근 경향을 바탕으로 본 연구에서는 구강건조증으로 향상된 안면부와 TMJ 부위의 염증성 통증 조절에 cinnamaldehyde가 영향을 미치는지 확인하고자 하였다.

구강안면부는 신경의 분포가 조밀하고 복잡하게 이루 어졌고 구조와 기능이 다양하며 신체적 및 심리적 조건 에 의해서도 많은 영향을 받고 있기 때문에 이곳에 통증 이나 질병이 발생했을 때 나타나는 임상 증상이 매우 다 양하고 복잡한 양상을 띠는 경우가 많다(Korean academy of orofacial pain and oral medicine). 이러한 구조로 인하여 실제 통증을 일으키는 조직 부위에서 거리가 있는 지점
에서 통증을 느끼는 연관통을 호소하는 경우도 적지 않 다(Guyton and Hall, 2000). 34세 여자 환자의 목빗근 쇄골두 의 통증 유발 지점으로 인하여 이통을 호소하여 성상신경 절차단술을 시행한 증례가 보고되었으며(Seo et al., 2004), 또한 상악 좌측 치아 및 치주 부위의 통증으로 내원한 환 자의 진단 결과 좌측 해면정맥동의 경계에 구형 종괴로 인한 신경절 압박으로 감마나이프(gamma-knife) 수술을 시행한 증례를 확인할 수 있었다(Yoon et al., 2008). 구강건 조증 및 안면부 통증 증상과의 연관성을 주장하는 연구 도 보고되었는데, 안면부 통증을 호소하는 환자군에서 구 강 건조감, 저작의 어려움, 미각 상실, 비정상적인 타액 분 비 등의 변화가 나타난 것으로 확인되었으며(Silva et al., 2011) 본 연구에서도 동일한 결과를 나타내었다.

우선 항산화 작용 및 항염증성 특징을 가지고 있는 cinnamaldehyde는 천연물로써 4-DAMP 투여하여 유도된 구강건조증 모델에서 타액 분비에 영향을 미치는지 살펴 보고자 하였다. 우선 cinnamaldehyde를 경구 투여한 뒤 발 생되는 생체 반응을 살펴보면 음수 량은 4-DAMP군에 비 해 모든 cinnamaldehyde 농도군에서 통계적으로 유의하게 감소되었으며, 식이 섭취량은 대체로 증가한 경향을 보였 고 특히 $\mathrm{C} 25, \mathrm{C} 50$ 군에서 통계적으로 유의한 증가세를 관 찰하였다. 타액 분비량 역시 cinnamaldehyde 투여군에서 농도 의존적인 증가세였으며 체중은 실험군에서 모두 증 가 하였고 특히 $\mathrm{C} 12.5, \mathrm{C} 25$ 군과 $\mathrm{C} 50$ 군에서 유의하였다. 선행 논문에서 실시한 단백정량분석 실험에서도 4-DAMP 군에 비하여 cinnamaldehyde 투여군에서 AQP5의 발현량 이 증가하였던 결과와 일치하였다(Choi et al., 2020).

또한 cinnamaldehyde를 안면부의 농도는 $\mathrm{C} 5, \mathrm{C} 25, \mathrm{C} 50$, $\mathrm{TMJ}$ 부위 농도는 $\mathrm{C} 5, \mathrm{C} 12.5, \mathrm{C} 25$ 로 각각 투여하였을 때 통계적으로 유의하게 통증이 농도 의존적으로 감소되는 결과를 보였다. 최근 연구 결과들을 살펴보면 안면 부위 통증 조절만 아니라 염증 조절에 cinnamaldehyde의 효 능이 입증되고 있다. 최근 한 연구 결과 보고에 따르면, cinnamaldehyde의 경구 투여로 인하여 과당으로 대사 증 후군을 유발한 실험 모델의 심장 조직에서 $\mathrm{IL}-1 \beta$ 수치의 감소로 인하여 심장 염증이 개선되는 것을 확인할 수 있 었으며(Kang et al., 2016), 알레르기 비염을 유발한 흰 쥐 실험 모델에서 cinnamaldehyde 복용으로 경감된 알레르 기 증상과 점막고유층, 호산구 수 및 혈장세포의 염증성 세포의 침윤이 감소된 실험 결과가 보고되었다(Hanc1 et al., 2016). 이러한 연구 결과와 일치하게 본 연구에서도 cinnamaldehyde의 경구 투여가 formalin의 투여로 유발된 
염증성 안면부 및 $\mathrm{TMJ}$ 통증 행위 반응에서 통계적으로 유의하게 감소되는 것을 관찰함으로써 통증 조절 및 경 감에 효과적으로 적용된다는 것을 입증할 수 있었다.

본 연구에서 4-DAMP 투여로 유도된 구강건조증과 증 가된 염증성 안면부 및 $\mathrm{TMJ}$ 통증 조절에 cinnamaldehyde 가 관여한다는 것을 알 수 있었다. 본 연구의 제한점으로 안면부 통증의 생태병리학적인 기전을 다루지 못하였지만 실험 결과를 바탕으로 cinnamaldehyde가 구강건조증 및 향상된 염증성 안면부 통증과 연관성이 높다는 것을 확 인할 수 있었다. 따라서 후속 연구에서는 cinnamaldehyde 가 타액 분비 및 구강악안면 통증의 신호를 매개하는 전 달 물질을 발현 및 규명하는 연구가 필요할 것으로 보인 다. 이상의 결과를 종합해보면, cinnamaldehyde는 구강질환 중 하나인 구강건조증을 비롯한 안면부 통증 조절의 예 방 및 치료제의 대안이 될 수 있을 것이라 사료된다.

\section{ACKNOWLEDGEMENT}

None.

\section{CONFLICT OF INTEREST}

The authors have no conflict of interest with the publication of this article.

\section{REFERENCES}

Aframian DJ, Helcer M, Livni D, Robinson SD, Markitziu A, Nadler C. Pilocarpine treatment in a mixed cohort of xerostomic patients. Oral Dis. 2007. 13: 88-92.

Alam K, Mahpara S, Mohammad MAK, Khan K, Richard AA. Cinnamon Improves Glucose and Lipids of People With Type 2 Diabetes. Diabetes Care. 2003. 26: 3215-3218.

Atkinson JC, Grisius M, Massey W. Salivary hypofunction and xerostomia: Diagnosis and treatment. Dental Clinics of North America. 2005. 49: 309-326.

Braga MA, Tarzia O, Bergamaschi CC, Santos FA, Andrade ED, Groppo FC. Comparison of the effects of pilocarpine and cevimeline on salivary flow. Int J Dent Hyg. 2009. 7: 126-130.

Brierley SM, Kelber O. Use of natural products in gastrointestinal therapies. Curr Opin Pharmacol J Microbiol Res. 2011. 2: 1-7.

Chaudhary SS, Tariq M, Zaman R, Imtiyaz S. The In vitro anti-acne activity of two unani drugs. Anc Sci Life. 2013. 33: 35-38.

Choi JH, Lee JH, Kim YH, Hyun KY, Park CM, Lee MK. Effects of cinnamaldehyde on salivary gland tissue in xerostomia model. Biomed Sci Letters. 2020. 26: 93-100.

Choi JH, Hyun KY, Lee MK. Orofacial Pain Anti-Inflammatory Activity of Extracts of Boswellia Serrata in Rats. Biomedical Science Letter. 2018. 24: 239-244.

Choi JS, Lim JY. Diagnosis and Treatment of Xerostomia. Korean Journal of Otorhinolaryngology-Head and Neck Surgery. 2016. 59: 424-429.

Choi SH, Kim KS, Kim ME, Lee DJ, Jin SB. Treatment Outcome and Prognosis of the Outpatients with Orofacial Pain. Korean Journal of Oral Medicine. 2006. 31: 155-165.

Dworkin SF, LeResche L. Research diagnostic criteria for temporomandibular disorders: review, criteria, examinations and specifications. critique J Craniomand Disord. 1992. 6: 301 -355 .

Dunn PM, Zhong Y, Burnstock G. P2X receptors in peripheral neurons. Prog Neurobiol. 2001. 65: 107-134.

Guyton AC, Hall JE. Textbook of medical physiology. 10th ed. New York, W.B. Sauunders Company. 2000, pp 557-558.

Hancı D, Altun H, Çetinkaya EA, Muluk NB, Cengiz BP, Cingi C. Cinnamaldehyde is an effective anti-inflammatory agent for treatment of allergic rhinitis in a rat model. Int J Pediatr Otorhinolaryngol. 2016. 84: 81-87.

Hossein N, Zahra Z, Abolfazl M, Mahdi S, Ali K. Effect of Cinnamon zeylanicum essence and distillate on the clotting time. J Med Plants Res. 2013. 7: 1339-1343.

Kim HJ, Kim YK, Choi JH, Lee MK. Anti-nociceptive Effects of Herb Extract (Solanum nigrum L., Taraxacum platycarpum, Portulaca oleracea L., Smilax china) on Acute Orofacial Pain in Rats. J of Korean Society of Oral Health Science. 2018. 6: 39-44.

Kang LL, Zhang DM, et al. Cinnamaldehyde and allopurinol reduce fructose-induced cardiac inflammation and fibrosis by attenuating CD36-mediated TLR4/6-IRAK4/1 signaling to suppress NLRP3 i nflammasome activation. Sci Rep. 2016. 6 : 27460.

Kim SO. Study on the mechanism of pain. Biowave. 2006. 8 .

Kim YK, Lee MK. Analgesic effects of triptolide and N-nitro-Larginine methyl ester in rat's temporomandibular joint pain model. J Korean Soc Dent Hyg. 2015. 15: 800-806.

Korean academy of orofacial pain and oral medicine. http:// www.kaom.org/info/part_02.html

Lee HJ, Kim YK, et al. Effects of red or black ginseng extract in a rat model of inflammatory temporomandibular joint pain. J Dent Hyg Sci. 2017. 17: 65-72.

Mariño R, Schofield M, Wright C, Calache H, Minichiello V. 
Self-reported and clinically determined oral health status predictors for quality of life in dentate older migrant adults. Community Dent and Oral Epidemiol. 2008. 36: 85-94.

Miranda RJ, Brunet LL, Lahor SE, Farre M. Salivary secretory disorders, inducing drugs, and clinical management. Int J Med Sci. 2015. 12: 811-824.

Myburgh NG, Hobdell MH, Lalloo R. African countries propose a regional planning oral health strategy. The Dakar report from 1998. Oral Dis. 2004. 10: 129-137.

Rao PV, Gan SH. Cinnamon: A Multifaceted Medicinal Plant. Evid Based Complement Alternat Med. 2014. 2014: 642942.

Richard JM, Clifford JW. Pain mechanisms and management: A central perspective. The Clinical Journal of Pain. 2000. 16: 144-156.

Seo YS, Chang SH, Park JY, Lim HJ, Lee HW, Yoon SM. Otalgia Caused by a Trigger Point in the Sternocleidomastoid Muscle - A case report -. Korean J Anesthesiol. 2004. 46: 497-500.

Silva LA, Siqueira JTT, Teixeira MJ, Siqueira SRDT. Xerostomia and salivary flow in patients with orofacial pain compared with controls. Archives of Oral Biology. 2011. 56: 1142-1147.

Silverman S Jr. Oral cancer: complications of therapy. Oral Surg Oral Med Oral Pathol Oral Radiol Endod. 1999. 88: 122-126.

Song BS, Moon JS. Dental caries and oral health behavior of kindergarten children a country area of Kangwondo. J Korea
Community Health Nursing Academic Society. 2002. 16: 123 $-134$.

Yair Z, Yacov B, Amos DK, Nir G, Tanya G. Disorders of the Oral Cavity in Parkinson's Disease and Parkinsonian Syndromes. Parkinsons Dis. 2015. 379482.

Yang GY, Lee JH, Ahn DK. Participation of NMDA and nonNMDA glutamate receptors in the formalin-induced inflammatory temporomandibular joint nociception. Int J Oral Bio 2007. 32: 59-65.

Yasuko I, Takafumi E, Mariusz TS, Hajime I. Acetylcholine Acts on M3Muscarinic Receptors and Induces the Translocation of Aquaporin5 Water Channel via Cytosolic Ca2+Elevation in Rat Parotid Glands. Biochimica et Bioptzvsiea Acta. 1998. 245: 835-840.

Yoon SH, Choi JH, Kim ST, Ahn HJ, Kwon JS. Nonodontogenic Toothache: Case Reports. Journal of Korean Academy Oral Medicine. 2008. 33: 401-407.

https://doi.org/10.15616/BSL.2020.26.4.327

Cite this article as: Choi JH, Lee MK. Effects of Natural Products on Acute Orofacial Pain Control Enhanced by Oral Disease. Biomedical Science Letters. 2020. 26: 327-335. 